Eskişehir Osmangazi Üniversitesi

Sosyal Bilimler Dergisi

Haziran 2019, 20(1), 1-15

DOI: 10.17494/ogusbd.595088

\title{
Çalışan Kadının Sorunlarının Çözümünde Dini İnanç ve Değerlerin Önemi*
}

\author{
M.Naci KULA**
}

Çalışan Kadının Sorunlarının Çözümünde Dini İnanç ve Değerlerin Önemi

Özet

Çalışma insanın yaşamında kendini ifade etme, yeteneklerini ortaya koyma ve geliştirmesine ve üretmesi ile sosyalleşmesini yansıtır. Tarihsel süreçte kadın zamanla farklı alanlarda ortaya çıkan iş sektörlerinde yer almıştır. Bununla birlikte çalışma hayatında bazı sorunları yaşamasına da neden olmuştur. Bu sorunlar arasında mesleki eğitimden, iş bulma ve yükseltilmeye varıncaya kadar sosyal haklardan yararlanmada yaşanabilen eşitsizlik yanında cinsel tacizler ve cinsiyet ayıımı, engellenme ve stres ve tükenmişlik gibi bazı sorunlar ifade edilebilir. Çalışma hayatında yaşanabilen bu sorunların çözümünde dini inanç ve değerler üzerinde durulacaktır. Zira bireyin haklarının korunması gibi toplumun temelini oluşturan unsurların sağlanmasında dini inanç ve değerlerin önemli bir rolü bulunmaktadır. Bu nedenle çalışan kadının sorunlarının çözümünde başta adalet, sorumluluk, şefkat, sevgi, saygı, doğruluk ve güven gibi dini değerlerle birlikte Allah'a iman ile ahirete iman da etkili olabilir.

Anahtar Kelimeler: Çalışan Kadın, Sorun, Dini İnanç, Değer
Significance of Religious Beliefs and Values in Solving Problems of Working Women

\section{Abstract}

This paper focuses on the role of religious beliefs and values in assisting women with solving the problems and hardships they encounter in business life. Women have always become a part of business life throughout history; before the industrial revolution, they were farmers cultivating the land; after it, they started to take part both in the production and the trading process of commodities. However, women some problems began to occur for them. Religious beliefs and values play significant role in solving the problems women face in business life. Religious beliefs and values have great importance in maintaining the existence of fundamental aspects of a society Therefore, in solving the problems of working women, religious values of justice, responsibility, affection, love, truthfulness, and faith in God and the afterworld, are responsible for everything they do should be taken into account.

Key Words: Working Women, Problems, Religious Beliefs, Values

\section{Giriş}

İnsan gerek yaşamını sürdürme, gerekse yeteneklerini keşfedip geliştirmede ve insani yönlerini ortaya koyma açısından çalışma eylemini gerçekleştirir. İnsanın yaşaması, hayatta kalabilmesi

*Bu çalışma, Eskişehir Osmangazi Üniversitesi Kadın Araştırmaları Merkezi'nin ev sahipliğinde 13-14 Ekim 2017 tarihlerinde düzenlenen I. Uluslararası Kadın Araştırmaları Sempozyumu'nda sunulan bildirinin makale haline dönüşmüş şeklidir.

** M.Naci KULA, Doç.Dr., Eskişehir Osmangazi Üniversitesi, Felsefe ve Din Bilimleri Bölümü, nkula@yahoo.com; ORCID ID orcid.org / 0000-0003-1763-9620

Makale Gönderim Tarihi 27/12/2017

Makale Kabul Tarihi $\quad 11 / 07 / 2019$ 
için beslenme, barınma, korunma, giyinme gibi birtakım intiyaçları vardır. Bütün bunların insanın kendisi tarafından hazırlanması, işlenmesi, oluşturulması ve öğrenilmesi gerekmektedir. Birey olarak insan bütün bu ihtiyaçları tek başına gerçekleştiremez. Sosyal bir varlık olan insan toplumdaki diğer insanların hatta kendisinden önce yaşamış olanların da aktarmış olduğu birikim ve bilgilerden yararlanarak hayatını sürdürme imkânına kavuşur. Bundan dolayı insanın üretmesi, keşfetmesi, öğrenmesi ve öğretmesi gibi kendine özgü olan çabaları çalışmanın insan hayatında var olan önemli bir özelliği olduğunu gösterir. (Mengüşoğlu, 1988, s.167) Dolayısıyla çalışma yalın, basit bir olay değil karmaşı ve çok yönlü bir örgüdür. İnsan çalışabilmek için çeşitli teknikleri öğrenmek, araçlar arayıp bulmak, geliştirmek zorundadır. İnsanın en önemli besini olan ekmeğin hazırlanıp sofrasına gelinceye kadar birçok insanın emeği yanında yüzyıllarca süren çalışması, deneyimi ve bilgisinin rolü söz konusudur. Bu çalışmalar, ekmeği hazırlamaya yarayan tekniğin ilerlemesi, iyileştirilmesi için devam etmektedir. Aynı şekilde insanın günlük yaşam bilgisi başta olmak üzere her konuda bilgisi de onun hazır olarak kendi varlığında bulunmadığından çalışma ve çabası ile gerçekleşir. Dolayısıyla insan bilgisini, bilim, felsefe, teknik ve sanatı bugünkü seviyeye ulaştırmak için çok çalışmak zorunda kalmıştır. Dolayısıyla çalışma insanı fizyolojik ihtiyaçları ile benzerlik gösteren hayvandan ayıran "temel fark" olarak karşımıza çıkar. Bu yönüyle insan çalışmak zorunda olan bir varlıktır. İnsan için çalışma, boş bir uğraş, olay, amaçsız, hedefsiz bir eziyet çekme değil; tersine hedefler, amaçlar planlar tarafından yönetilen bir aktif davranış biçimidir. Bu nedenle çalışma bir yandan değerler, öte yandan önceden görme ve belirlemeyle bağlantılıdır. Bütün bu özellikleriyle insan hayatında çalışma çok unsurlu karmaşık bir yapı olarak karşımıza çıkar. ( Mengüşoğlu, 1988, s. 167-168)

\section{Problemin Ortaya Konması}

İhtiyaçlar ve beklentiler, insanın üretmesinde ve buna bağlı çalışma alanları oluşturmasında etkilidir. Hayatını sürdürmede beslenmek için sebze, meyve, tahı ürünleri yetiştirmek ve hayvancılık gibi uğraşılar tarım ve hayvancılık alanındaki çalışma ortamı içerisinde hem erkeğin hem de kadının yer almasına neden olmuştur. Sanayi devrimi ile örgütlü üretimin doğal sonucu olarak farklı çalışma alanları oluşmuş, burada da kadınların yer aldığı görülmektedir. Çocuk bakıcılığı ev temizliği gibi işler yanında özel sektörde veya kamuda farklı alanlarda iş̧̧i ya da memur statüsünde çalışan kadının yaşadığı sorunlar, başta onun çalışma verimini olumsuz yönde etkileyeceği gibi aile ve sosyal hayatında da bir takım olumsuz izleri oluşturabilecektir. Bu nedenle çalışan kadının çalışma hayatında veya çalışmasına bağlı karşılaştığı sorunların ana hatlarıyla neler olduğu ve bunların çözümünde de önemli etkenlerden biri olarak belirtilebilecek manevi değerlerin rolü bu konunun problematik yönünü oluşturmaktadır.

\section{Kadının Çalışma Hayatı ve Karşılaştığı Sorunlar}

Başlangıçta ev ve çocuk bakımı yanında tarım iş̧̧iliğinde yer alan kadın, sanayi devrimi ile birlikte değişen tarımsal üretim koşullarından, ekme-biçme dışındaki işlerde de istihdam edilmesiyle birlikte özellikle üretilen ürünlerin satışı noktasında hizmet sektöründe de yer almışlardır.( Küçük, 
2015 , s. 3) Aynı zamanda kadın zaman içerisinde ekonomik nedenlerle ekonomik özgürlügünün kendisine kazandırdığı kimlik ile ( Erkek\& Karagöz, 2009, s.1) ve eğitim düzeyinin artmasıyla da çalışma hayatında farklı sektörlerde ve ücretli çalışanlar arasında yer almaya başlamıştır. Bu itibarla Türkiye'de de ilk kez ebelik eğitimiyle 1843 de çalışma hayatında yerini almıştır. 1897'de ise iş yaşamına ücretli iş̧̧i olarak katılan kadınlara, 1913 yılında da devlet memuru olma hakkı verilmiştir. Bunun ardından bir yıl sonra kadınlar, tüccar ve esnaf olarak da iş hayatına girmişlerdir. 1923 yılında Cumhuriyetin ilanını izleyen ilk on yılda gerçekleştirilen reformlarla, kadınların eşit vatandaşlar olarak haklarının kazanılması ve toplumun yeniden yapılanması sağlanmıştır. Buna bağlı olarak da kadınların eğitim, çalışma yaşamı, siyaset gibi kamu alanlarına girmesi mümkün kılınmış, eşitlikçi kamu politikaları ile devlet bu katılımı özendirmiş ve desteklemiştir. Türk kadınları, yerel ve genel seçimlerde seçme ve seçilme hakkına 1930 ve 1934 yıllarında kavuşmuştur. (Gül\&Yalçınoğlu, Atlı, 2014, s.170) Bununla birlikte istatistiklere göre, Türkiye'de yetişkin her on erkekten yedisi, kadınlardan ise yalnızca üçü ev dışında bir işte çalışmaktadır. Uluslararası Çalışma Örgütünün (ILO) verilerine göre, dünya genelinde kadınların işgücüne katılım oranı \%51,6 iken bu oran Avrupa Birliği ülkelerinde de $\% 52,9^{\prime}$ dur. Kadınların istihdam oranı dünya genelinde $\% 48$ iken, AB genelinde \%48,3'e çıkmaktadır. (Gül\&Yalçınoğlu, Atlı, 2014, s.172)

Türkiye İstatistik Kurumu (TUIK) Ocak 2013 istatistiklerine göre, Türkiye genelinde işgücüne katılım oranı \%50.8'iken bu oran 2016 da \% 52 olarak gerçekleşmiştir. 2013 yılında erkeklerde bu oran \%71,5 iken 2016 da \%72, kadınlarda ise \%30.8 iken 2016 yılında \%32.5 olarak gerçekleşmiştir.http://www.tuik.gov.tr/PreHaberBultenleri.do?id=21573)

Son üç yılın rakamları göz önüne alındığında erkek ve kadınların işgücüne katıım oranlarında çok fazla bir artışın olmadığı gözlenmektedir.

2013 verilerine göre çalışan kadınların yaklaşık 42.4'ü Tarım sektöründe iken, 2016 da bu oran \%6.3' e düşmüş tarım dışı sektörlerde ise \% 67.9 iken bu oran 2016 da \%68.8 yükselmiştir. (http://www.tuik.gov.tr/PreHaberBultenleri.do?id=21573)

Dünyada ve Türkiye'de kadınların kayıt dışı olarak çalıştıııması, erkeklere göre daha fazladır. Kasım 2015 TUiK istatistiklerine göre, kayıt dışı çalışma; Türkiye genelinde \%47.4, neredeyse çalışan iki kadından birinin kayıt dışı olduğunu söylemek mümkündür. Tarım dışında ise erkeklerin oranı \%19.9 iken kadınların oranı \%24.6 dir. Kayıt dışılık, daha çok tarımsal faaliyetlerle uğraşanlarda özellikle de ücretsiz aile işçilerinde \%95 olarak yoğunlaşmaktadır. (https://www.dunya.com/gundem/kayit-disi-calisma-kadinlarda-yuzde-47-erkeklerde-yuzde-28haberi-290666)

2016 Tuik verilerine göre nüfusun \%49.8 'ini oluşturan kadınların ülkemizde iş yaşamında yaşadıkları sorunların ardında önemli ölçüde ekonomik ve sosyo- kültürel etkenler söz konusudur. Nitekim öncelikle kadının anne olmasından kaynaklanan rolü ve gerçekleştirdiği aile içi görevleri nedeni ile yüzyıllar boyunca ekonomik faaliyetlere katılımda erkeklerin gerisinde kalmıştır. Özellikle kadının aile içi görevlerinin ekonomik olarak değerli sayılmaması kadının konumunu büyük ölçüde etkilemektedir. (Çullu,2009, s.17) 
Kadınların çalışma yaşamında karşılaştıkları engeller, çoğunlukla salt cinsiyetleri yüzünden önlerine çıkar. Bununla ilgili sorunlar, eşit işe eşit ücret alamamaktan, kadınların çocukların bakımından, ev işlerinden sorumlu görülen kişiler olarak üstlendikleri sosyal rollere kadar birçok değişik konuda sıralanabilir. (Gül\&Yalçınoğlu, Atlı, 2014, s.174)

Çalışan kadınların karşılaştıkları sorunları çalışma koşullarından kaynaklanan sağlık sorunları, kadının eğitimi ve çocuk bakımı aile içi ilişkilerin sonucunda ortaya çıkan sosyal sorunlar ve işyerinden kaynaklanan sorunlar olarak gruplandırılabilir.( Şahin, 2005, 75vd) Çalışan kadın için işyeri ortamından kaynaklanan sağlık sorunları önemli bir yer tutar. Kadınların işyeri ortam koşulları nedeniyle, hastalıklara yakalanma olasılıkları erkeklere oranla daha yüksek bulunmaktadır. Uzun süren çalışma saatleri kadınlar için zorlayıcı olup, erkeklere göre yorgunluk hissetmeleri daha kolay olmaktadır. Sürekli ayakta kalarak çalışmak kadınlar için sağlık açısından uygunsuz bir çalışma şeklidir. Varis, bel fıtığı, taban çökmesi, ayaklarda şekil bozukluğu gibi fiziksel sorunlara yol açabilir. Ayakta yapılan işlerde çalışan kadınlara oranla, oturarak çalışan kadınlarda menstruasyon düzensizlikleri daha az görülmektedir. Ayakta durarak çalışanlarda erken doğum olasılığı daha yüksektir. Kadınların hamilelik dönemlerinde işyerlerinde toksik içerikli etkenlere maruz kalmaları durumunda, anneyi etkileyen bu maddelerin aynı zamanda fetüsü da etkileyebildiği, düşüklere ve sakat doğumlara yol açtığı bilinmektedir. İşyeri ikliminden kaynaklı çeşitli psiko-sosyal risk etmenleri (monoton iş, mobbing, stres v.b.) de gebelikle ilgili komplikasyonlara, spontan düşük, erken doğum gibi sorunlara neden olmaktadır. (Gül\&Yalçınoğlu, Atlı, 2014, s.17) Çalışan kadının sosyal sorunları arasında ev işleri ve çocuk bakımı, iş aile çatışması, aile içerisindeki sorumlulukları vb. sorunları sıralamak mümkündür. (Şahin, 2005:75-76; Karaali, 2016: 68-73; Çullu, 2009: 85 vd ) Çoğu çalışan kadının iş hayatı yanında ev işleri varsa çocuğunun bakımı ve aile ile ilgili sorumlulukları önem arz eden sosyal boyutlu durumudur. ( Şahin, 2005:76) Nitekim DPT'nin Türk Aile Yapısı araştırmalarına göre, hane halkı reislerinin \% 76'sı için kadının aile içindeki en önemli görevi, ev işi ve çocuk bakımı olarak ifade edilmiştir (Koray, 1993, 72.nakl.Çullu, 2009: 85) Dolayısıyla kadının toplumsal yapı içerisinde görev ve sorumlulukları gündeme geldiğinde ilk akla gelen iyi anne, iyi es, iyi ev kadını olmasıdır. Bu durumda kadının konumuna ilişkin olarak kadınların çalışmasının olumlu bir değer haline gelemediği dikkati çekmektedir. Dikkat çeken husus ise, üniversite mezunu kadınların \% 72'sinin de bu görüsü paylaşmasıdır. ( Çullu, 2009: 85)Dolayısıyla çalışan kadın için işte ve ailede eş zamanlı ortaya çıkan intiyaç ve talepler, baskılar oluşturmakta ve kişilerin öncelikler konusunda çelişkiler yaşanmasına neden olmaktadır. Kadınların ev dışında çalıştıklarında dahi ev içindeki sorumluluklarında pek bir değişikliğe rastlanmadığı gözlenen bir durumdur.

Kadınların çalışma hayatı içinde oldukça önemli bir yer tutan ev işleri, çoğunlukla kadınlar tarafından yerine getirilen, ücretsiz ve özel nitelikli bir çalışma türüdür. Ev işleri, kadınlar için yaşamlarındaki en önemli konulardan biridir. Çalışan kadın eve geldiğinde ikinci bir işgününü, iş zamanını yaşamaktadır. İşten yorgun bir şekilde evine gelen kadını, bulaşık, çamaşır, temizlik ve ütü vb. gibi yapılması gereken ev işleri beklemektedir. ( Karaali, 2016: 69; Yaşar, 2014:44) 
Ev işleri ile ilgili sorumluluk anlayışı ya da destek evden eve değişmektedir, ancak ev işleri yapılırken eşler arasında sorumluluk ve iş paylaşımının eşit olmaması bu konuda sorunlar yaşanmasına neden olmaktadır. 2006 yılında, "Aile Yapısı" adında yapılan araştırma verileri incelendiğinde, ev işlerinde paylaşım oranları; kadınlarda yemek yapma oranı \%87,1 erkeklerde \% 2, kadınlarda ütü yapma oranı \% 84,3, erkeklerde \% 2,2, kadınların sofra kurup kaldırma oranı \% 74.1, erkeklerde ise \% 2,4"dür. (Mercanlıoğlu, 2009:40, nakl. Karaali, 2016: 69 )

Bu veriler ışığında kadınlardan çalışma yaşamlarının yanı sıra ev işleri, çocuk bakımı ve evlilik gereksinimlerini de aynı şekilde yerine getirmeleri beklendiği görülmektedir. Bu beklenti çalışan kadınlar üzerinde büyük bir yük oluşturmakta ve kendilerini tam gün işlerine vermelerini engellemektedir. Aynı zamanda bu durum çalışma verimlerini de düşürmektedir. (Karaali, 2016: 69)

Çalışan kadın için ̧̧̇ ve aile ile ilgili kendisinden beklenen rollerin yoğunluğu aile içi ilişkileri de etkilemektedir. Özellikle iş ortamındaki yoğunluk, rol belirsizlikleri ya da rol çatışmaları gibi durumlar aile içinde gerginlik iş sorunlarının aile ortamına yansımasına neden olabilmektedir. Aynı şekilde ev ve çocukla ilgili sorumlulukları, kadınların iş hayatını olumsuz etkileyerek sorunlar yaşamasına neden olmaktadır. Dolayısıyla iş ile aile rolleri arasındaki çatışma, iş-aile çatışması ve aile-iş çatışması şeklinde iki yönlü olarak ortaya çıkmaktadır. Örneğin, uzun süre çalışmanın eve ayrılan zamanı kısaltması ve ailedeki sorumlulukları aksatmasıyla, bireyin iş rolü sorumlulukları aile rolü sorumluluklarını engellemektedir, bunun sonucunda iş-aile çatışması yaşanmaktadır. Aile ile ilgili sorumluluklar iş rolü sorumluluklarını engellediği zaman da aile-iş çatışması yaşanmaktadır. (Karaali, 2016:70)

Çalışan kadının işyerinden kaynaklanabilecek sorunların içerisinde kişilerin nitelik bakımından eşit olmalarına rağmen, sadece cinsiyetlerine bağlı farklı muamele ile karşılaşmaları durumu olarak tanımlanan cinsiyet ayırımı önemli ölçüde dikkat çekmektedir. Yapılan işlerin üçte ikisi kadınlar tarafından yapılmaktadır, buna karşıık kadınlar dünyadaki oluşan gelirin sadece onda birini almaktadır. Bu veriler yapılan ayrımcılığı daha görülür hale getirmektedir. (Cesur, 2009:60; nakl. Karali, 2009: 58)

ILO’nun 1997 yılında yayınladığı bir rapora göre, dünya genelinde çalışan kadınların yarısından fazlası cinsiyet ayrımına göre sınıflandırıımış durumdadır. İ̧ yaşamında bu sorunla karşılaşan kadınlar, sabırsızlık, rekabet eğilimi ve üzerlerinde sürekli baskı hissettikleri için bir ciddi rahatsızlık hissetmektedirler.. Diğer yandan cinsiyete dayalı ayrımcilığın olduğu örgütlerde kadınlar kariyer yapabilmek için erkeklerden daha fazla performans göstermek zorunda kalabilmektedirler. Dolayısıyla bu iş yaşamında kadına yönelik cinsiyete dayalı ayrımcılık, çalışan kadının iş gücüne katılım oranını, kariyer hedeflerine ulaşma hızlarını ve ücret düzeylerini olumsuz yönde etkilemektedir. Ayrıca iş yaşamında cinsiyetle ilgili göstergeler (pozisyonlar, kararlara katılım, ücret vb) örgütsel sistem içinde bulunan ve örgüt kültürüne de yansıyan unsurlar olup, buna bağlı olarak tarihsel süreç içerisinde de erkek egemen yapıların varlığı, kadınların çalışma hayatındaki görevlerini ve statüsünü belirlediğinden işverenlerin iş görüşmelerinde pozisyona göre değerlendirme yaparken cinsiyet temelli değerlendirme yapmaları ve cinsiyet ayrımcılığına gitmeleri kadınsı ve erkeksi iş tanımlarının yapıl- 
masını da beraberinde getirmektedir. Bununla birlikte işverenlerin, kadın ve erkek çalışanların işle ilgili beklentilerini, görev tanımlarını ve performanslarını değerlendirirken yoğun bir biçimde cinsiyet ayrımcılığının etkisinde kaldıkları da görülmektedir. (Yaşar, 2014: 49)

Kadınların çalışma hayatında karşılaştığı bir diğer sorun ücretlendirmede yapılan ayrımcılıktır. Her ne kadar kadınlara çalışmaları karşılığında ödenen ortalama ücret son yıllarda bir miktar artış gösterse de erkeklere ödenenin altında kalmaktadır. ( Yaşar, 2014: 50) Örneğin "Kadın Emeği" raporuna göre ülkemizde 2016 verileri çerçevesinde küresel ölçekte yapılan toplumsal cinsiyet araştırmalarında ücret eşitsizliği sıralamasında Türkiye'nin 145 ülke arasında 98. sırada yer aldığı; ayrıca ücretli çalışmada kadınların erkeklere göre günlük 23 dakika fazla çalıştığı, ancak emeğin karşılı̆̆ını alamadığı belirtilmektedir. Dünya Ekonomik Forumu (2016) cinsiyet eşitsizliği ölçeğini kullanarak yapılan hesaplamada da; Türkiye'de bir kadının günlük ortalama 1 dolar kazanırken, bir erkeğin günlük ortalama 2.27 dolar kazandığı belirtilmiştir.. Yine aynı hesaplama yöntemi ile yapılan incelemede; bir kadının ortalama yıllık maaşı 12 bin 162 dolarken erkeğin ortalama yıllık maaşı 27 bin 672 dolar olduğu görülmektedir. ( Bkz. http://gazetemanifesto.com/2017/03/08/kadinemegi-raporu)

Çalışan kadının iş ortamında karşılaştığı sorunlar arasında zaman zaman yaşanan mobbing uygulamalarıdır. "Yıldırma, bastırma, yok sayma, bezdirme veya psikolojik şiddet olarak ifade edilebilen mobbing, birçok olumsuz sonucu beraberinde getiren bir işyeri kâbusudur". (Akdemir,\&Duman,2016: 29) Dolayısıyla mobbingin olduğu işyerlerinde çalışanlar motive olamamakta, işyerine karşı güven, bağlanma ve özdeşleşme hislerini kaybetmekte ve iş tatmini bulamamaktadır. Aynı zamanda mobbing, işyeri ortamında çatışmaya ve genel bir verimsizlik durumuna neden olmaktadır.(Cevher\&Öztürk, 2015:861) Mobbing'e neden olan faktörler genelde bireysel sosyal ve örgütsel olmak üzere 3 gruba ayrılabileceği ifade edilmektedir. Çalışanı grup kuralını kabul etmeye zorlama, can sıkıntısından dolayı zevk arayışı, bencillik vb, bireysel, statü farkıııkları, yaşam tarzlarındaki değişiklikler, aşırı yoğun rekabet, değerlere bağılığın azalması vb sosyal ve iş ortamındaki istenmeyen kişiden kurtulma, işverenin daha pahalı ücretle çalışanın ucuz ücretle çalışanla değiştirilmek istenmesi vb. örgütsel faktörler dışında iş ortamlarında psikolojik yıldırma (mobbing) davranışlarına neden olan diğer etmenler "parlak bir kariyer, göz alıcı bir güzellik, üstün duygusal zekâ, farklı inançlar, gruplar, ırk ve kökenler, oldukça genç bir kişi, yaşlı bir hanım veya bir bey, kadınlar arasında tek bir erkek, erkekler arasında ise tek bir kadın" şeklinde sıralanabilir. (Cevher\&Öztürk, 2015:864-865)

\section{4. İnsan- Dini İnanç ve Değerler ilişkisi}

Insanın kendine özgü yönlerinden biri de çalışma yanında inanan bir varlık oluşu ve birtakım değerlere sahip olmasıdır. Dini inanç ve değerler aynı zamanda insanın çalışma yönünü de ilgilendiren, geliştiren bu yönüne de hitap eden bir özelliği söz konusudur. Zira bir dine ya da kutsal bir varlığa inanan insan inancı gereği çalışmanın erdemli bir davranış olduğunu, çalışmasının karşılığını alacağını ve bundan dolayı da ulvi bir amaca hizmet ettiği bilinciyle hareket ettiğini düşünür. ( Şe- 
kerci,2001, s.29-30) İnsanı anlamlı kılan değerler içerisinde önemli bir yeri olan dini değerler, çalışmanın önemini ortaya koyacak ilkelere sahiptir. Bu değerler içerisinde yer alan sorumluluk değeri de, çalışmanın özünü kapsayacak nitelikte olan bir değerdir. Zira sorumluluk değeri sayesinde insan, kendisine verilen veya üzerine aldığı işin sonuçlarını üstlenmeyi, bir işi istenen nitelik ve nicelikte yapmayı gerçekleştirir. ( Hökelekli, 2013, s.57) İnsanın çalışma, iş yapma eylemini de önemli kılan inanma fenomeni, insan hayatının diğer fenomenleri gibi temelini insanın varlık yapısında bulur. İnanma fenomeni ile günlük hayatın bütün yapıp etmelerinde karşılaşmaktayız. İnsan günlük yaşamında herhangi bir refleksisyona/yansımaya dayanmadan diğer insanlara inanmakta eylemlerini ve işlerini bu inanma üzerinde gerçekleştirmektedir. Örneğin günlük yaşamda birbiriyle belli bir saate buluşmak üzere sözleşen ya da kendi aralarında yaptıkları alışverişte, mal alıp satmada anlaşan kişilerin bu davranışlarını gerçekleştirmede ve eylemlerinin süreklilik kazanmasında birbirlerine olan inanmaları etkili olmaktadır. Ancak ilişkilerin oluşması ya da sürdürülebilmesinde etkili olan bu inanma eylemi tarafların birbirlerine karşı farklı davranmaları halinde zayıflayabilir hatta kaybolabilir. (Mengüşoğlu, 1988, s.196) İnsanın günlük hayatında anlamlı ilişkiler kurmasında ya da insani ilişkilerinde sürekliliği oluşturmada etkili olan insanın varlık yapısında var olan inanma fenomeni yönetilen bir boyut kazandığında ise dini inançtan bahsedebiliriz. Yönetilen inanma , insanüstü doğa üstü olan bir şeye inanmaktır. İnsanüstü doğa üstü olan şey insan için bir dayanak olmaktadır. Dolayısıyla bu inanma dini inanma biçimidir. ( Mengüşoğlu, 1988, s.201) Dini inanç insanın Allah'la ilişkisi yanında günlük hayatında diğer insanlarla olan ilişkisine yön veren bir özelliğe sahiptir. Dini inançlar ve bunlardan beslenerek oluşan dini değerler insanın ihtiyaçları, arzu, istek ve ilgileriyle ilişkili olarak gerçekleştirdiği çalışma hayatına da etki edebilecek bir fonksiyonu bulunmaktadır. Nitekim Peygamberimiz dönemine baktığımızda kadının çalışma hayatında H.z. Hatice örneğinde olduğu gibi ticaretle meşgul olan, Ku'aybe binti Said el_eslemi Hemşirelik, Peygamberimizin eşi H.z Zeynep deri işleyen sanatkar, Abdullah. b. Mesud'un han8mı Raite de kendi eliyle yaptığı bazı el işi ürünleri satarak ailesinin geçimine katkı sağlamak suretiyle sosyal hayatta farklı iş alanlarında yer alan kadınları görmekteyiz. ( Bkz. Gözütok, 2016: 181-182)

\section{5. Çalışan Kadının Sorunlarının Çözümünde Dini İnancın Önemi}

Bireyin kişilik bütünlüğünü sağlamada ve kişiliğine bir yapı ve devamlılık kazandırmada dini inançların önemli bir yeri bulunmaktadır. Dinin özünü oluşturan iman yapısında kabullenme, tasdik etme, bağlanmayı barındırır. İnsanın "bütün kainat ve bizzat kendi üzerinde hakimiyetini kabul ettiği duyular üstü yüce kudret ve kuvvet sahibi bir varlığa yönelme, mutlak iradesine güvenerek içsel bağlarla O'na bağlanma" olarak ifade edilebilecek dini inanç) kişinin bütün benliğinin katılımıyla zihinsel, duygusal ve iradi olarak kişiliğin organizasyonunu sağlar. ( Hökelekli, 2009: 59-60) Aynı zamanda dini inanç, hayatın merkezi yönünü teşkil edip, inananların "nihai anlam"a ilişkin sorularına cevap verir. (Köse\&Ayten, 2012: 111) Dolayısıyla birey dini inançları sayesinde hayatının amacını, görev ve sorumluluklarının neler olduğunu ve hayatın içerisinde karşılaştığı sorunlar karşısında inançlarının ona nasıl destek olacağına ilişkin sorularına da cevaplar bulabilir. Çalışan kadının da yaşadığı sorunların çözümünde dini inançların önemli bir yeri bulunmaktadır. Zira dini inançlar bireyin tutarlı davranmasına, daha derinden onu etkileyerek daha yüksek düzeyde davranış üret- 
mesine yardımcı olur. ( Karaca, 2015: 137) Bu nedenle işyerinde çalıştırdığı kadının haklarını yerine getirmede, ona saygılı davranmada, çalıştığının karşıı̆ı̆ı vermede, herhangi bir ayırımcılığa yol açmamasında dini inançların önemli bir etkisi olabilir. Dini inançlar içerisinde özellikle Allah'a ve ahirete iman bu konuda daha etkili olabilmektedir. Zira iman esaslarının temelini oluşturan Allah inancı kişinin iç dünyasını imar eder, düzene sokar, kişiliğini ve sorumluluk duygusunu geliştirir. Aynı zamanda bireyi, Allah sevgisi ve Allah karşısında duyarlıı̆̆ ahlaki davranışlarına da yansıyacaktır. Allah için sevmek, iyilik yapmak, yardımda bulunmak, insanların ve bütün varlıkların hak ve hukukuna riayet etmek, kimseye haksızlık yapmamak, dürüst ve samimi olmak, dolayısıyla Allah'ın emrettiği gibi güzel ahlaka sahip olmak, Allah inancının inananda dışa vurumlarından olan önemli yönlerdir.( Acar, 2012: 161 vd) Allah inancının insana kazandırdığı bu yönler çalışan kadının işyerlerinde yaşanan başta mobbing olmak üzere ücret eşitsizliği cinsiyet ayırımına dayalı davranma gibi bazı sorunların çözümünde manevi destek özelliğini gösterebilir. Gerek işveren ya da yönetici gerekse iş ortamında kadınla çalışanlar onun da kendilerini gibi değerli bir varlık olduğunu dikkate almada ve Yunus Emre'nin ifade ettiği gibi "Yaratandan Ötürü Yaratılanı Sevmek" anlayışı içerisinde davranmada Allah inancı etkili olabilir.

Dini inançlar içerisinde Allah inancı yanında çalışan kadının sorunlarının çözümünde manevi destek özelliğini taşıyan bir diğer inanç Ahirete imandır. Kur’an-ı Kerimde Allah’a imanla birlikte 26 yerde zikredilen Ahirete iman ( Uyanık, 2010: 23) özünü öldükten sonra insanın yeniden diriltilip bu dünyada yaptıklarından dolayı Allah'ın huzurunda hesaba çekileceği ve yaptıklarının karşılı̆̆ıı alacağı inancını oluşturur.( Uyanık, 2010: 24; Şentürk, 2017:39) Bu yönleriyle ahiret inancı öncelikle insanın ölümlü bir varlık olduğunu ve öldükten sonra da diriltilip yaptıklarından hesaba çekilerek karşılığını alacağı anlayışını kazandırarak insani ilişkilerinde görev ve sorumluluklarında dikkatli davranmasına imkan sağlayabilir. Bu itibarla çalışan kadına karşı davranışlarda, onun çalışma ortamında erkeklerin sahip olduğu imkan ve temel haklarda ve emeğinin karşılığını vermede, onu rahatsız edecek davranışlardan kaçınmada ve aile ortamında da ona yardımcı olmada, ev işlerinde destek olmada gerek eş gerekse işveren ve yönetici ile çalışma arkadaşları daha özenle hareket etmeye çalışabilir. Çünkü ahiret inancına sahip olan kişi, yapacağı her davranışın ahirette hesabını vereceğini ve karşılığını alacağını düşünerek yüksek ve ahlaki değerlere bağlı davranışlar ortaya koymaya gayret edebilir. Bu nedenle ahiret inancının çalışan kadının yaşayabileceği sorunların oluşmaması noktasında motivasyonel bir rolünden bahsedebiliriz.

Ayrıca kendimizi, dünyayı ve davranışlarımızı anlamlandırma bakımından da ahiret düşüncesi çok önemli bir bakış açısı sunmaktadır. Ahiret düşüncesi insana bu dünyada bir amaç ve hayat için bir anlam sunmaktadır. Ahiret yüksek/yüce değerleri temsil eder. Dolayısıyla dünya, hayatın salt maddi yönünü, sırf dünyevi kazanımları ve geçici tatminleri ifade ederken, ahiret ise bu hayatın yüce ve ahlaki değerlerini oluşturan diğer tarafına işaret eder.( Hökelekli, 2007:7) Bu nedenle kadının çalışması ve çalışma hayatında karşılaştığı sorunlarla ilgili makul çözümler oluşturmada ve kadının ev ve iş ortamında uyumlu ve çatışmasız bir şekilde iş hayatını sürdürme noktasında makul bakış açısı kazandırmada ahiret inancı ölümü ve ölüm sonrası yapılanlardan sorumlu olunacağı 
düşüncesi ile olumlu katkıda bulunabilir. Zira insanın olaylara bakışında toplumdaki geleneksel inanç ve tutumlar yanında kişisel çıkarları önemli rol oynayabilir, olayları sağlıklı değerlendirme ve makul davranma açısından ise yüksek değerler etkili olur. Ahiret inancı da sahip olduğu yüksek anlam ve amaçlar sayesinde sıradan, basit amaçların ötesine geçmeyi sağlayabilir. Bu nedenle ahiret inancı çalışan kadının sorunlarının aşılmasında yardımcı olur.

\section{6. Çalışan Kadının Sorunlarının Çözümünde Dini Değerlerin Önemi}

İnsan, davranışlarında genelde belli bir amacı, hedefi gözetir. Gelişigüzel rastgele davranmamaya özen gösterir. Çünkü insanın hedefleri amaçları doğrultusunda davrandığında yaptıklarının kendisi için bir değeri olduğunu fark eder. Böylece "değer" insan hayatında yapıp etmelerinin anlamlı olmasını sağlar ve onun davranışlarının kendi içinde gerekli olduğunu ortaya koymasında etkili olur. ( Mengüşoğlu, 1988: 97) Dolayısıyla insan hayatında değerler onun yapıp etmelerine yön verir, davranışlarını yönetir. (Mengüşoğlu, 1988: 99) Yapıp-eden bir varlık olarak insanın bütün yapıp-etmeleri mutlaka bir "değer" ile ilgilidir. O halde değer; "insanın yapıp-etmelerini belirleyen ilke ya da ilkeler" olarak tanımlanabilir. "Yapıp-etmelerimizi belirleyen, yöneten, yönlendiren, onların temelinde yatan ilkelerdir." Bir "değer" ile ilişkili olmayan hiçbir insan davranışı yoktur.(Uysal, 2003: 52; Kula, 2012:193) İnsan hayatında tutum ve davranışlarını belirlemede etkili olan değerler genel olarak estetik, teorik (bilimsel), ekonomik, siyasal, sosyal ve dini olmak üzere kategorize edilmektedir. Bununla birlikte değerlerin kesin sınırlarını çizerek ayrıştırmak mümkün olmayabilir. Çünkü değerlerin kesin çizgilerle ayrılamaması, onların insana özgü ve onun hayatını anlamlı kılııı ve yön verici oluşlarından kaynaklanmaktadır. Sosyal bir davranış örneğin birisine yardım etme aynı zamanda ahlaki ya da dini bir değer özelliğini taşıyabilir. Bununla birlikte değerler, referans kaynakları ve fonksiyonel oldukları alanlar göz önüne alındığında ise, farklı şekillerde tasnif edilebilmektedir. Yukarıda da belirtildiği gibi, genelde altı grupta toplamak adet olan değerler sistemi içinde yer alan dini değerler, referansını dinden alır. Zira değerlerin dayandığı önemli kaynaklardan biri, toplum olmakla birlikte diğer önemli bir kaynak da toplum üstü kaynak olarak dindir.( Kula, 2012: 194) Çünkü din, insana varoluş içinde kendini bir yere yerleştirmeye imkân veren başvuru çerçeveleri hazırlar, ona hayatı için rehberlik yapar.(Hökelekli, 1998: 116) Dolayısıyla dinler bu fonksiyonları çerçevesinde mensuplarını belirli değer perspektiflerini izlemelerini teşvik ederler. Dinin değerleri, inançları, ritüelleri, duyguları, ahlaki kodları ve toplumu birleştirici özelliği nedeniyle pek çok insan belirli değer önceliklerini genelde dinde bulur. (Mehmedoğlu,2006: 258; Kula, 2012 : 194) Bu nedenle çalışan kadının yaşadığı sorunların çözümünde dini değerlerden adalet, sorumluluk, şefkat, sevgi, saygı, doğruluk ve güven gibi bazı dini değerler önemli bir rol oynar. Çalışan kadının yaşadığı sorunların çözümünde yararlanılabilecek bu değerlerin önemi şu şekilde açıklanabilir.

Adalet değeri eşitliği gözeterek yapılacak olan şeylerde tarafsız ilkeli dürüstçe hareket etme ve hak sahibinin hakkını verme ile bir şeyi yerli yerine koyma yanında ölçülü, dengeli davranmayı ihtiva eden bir dini değerdir. ( Hökelekli, 2013: 75) Kur’an-ı Kerimde adil olma öğütlenir ve adaletin hayatın temel özelliği olduğuna vurgu yapılır. (Bkz. Elmalı, 1997: 304 vd) Allah işi ehline vermeyi, davranış ve hükümlerde eşit davranarak hak sahibinin hakkını vermeyi emreder ( Kur'an, 4/58) Aynı şekilde Hz. Muhammed hayatı boyunca gerek sözleri ve gerekse davranışlarıyla adalet örnek- 


\section{M.Naci KULA}

leri sunmuşur. Veda Hutbesinin bir yerinde şöyle demiştir: "Hepiniz biliyorsunuz ki müslümanlar birbirinin kardeşidirler. Gönül hoşluğu ile vermedikçe hiçbir kimseye kardeşinin malını almak helal olmaz. Nefislerinize zulmetmeyiniz." Ayrıca "Adaletsizlikten kendinizi koruyunuz. Çünkü o, Hesap Gününde zulme denktir." buyurmuştur.( Bkz. Kayaoğlu, 1986: 202) İslam’da adalet değerinin sosyal hayattaki yeri ve önemini ortaya koyan şu örnek de dini değer olarak adaletin insan hayatındaki yerini gösterir niteliktedir. Hz.Ömer'in, Ebu Musa el.Eşari'ye yazdığı bir mektup vardır. Bu mektup alimler arasında pek ünlüdür. Halife Ömer'in İslam'daki kadılı̆ın esaslarını belirttiği bu mektubu şöyledir. "Sana takdim edilen delilleri dikkatle incele üzerinde iyi düşün, şunu bil ki, geçerli hale getirilmeyen bir haktan söz etmek, boşunadır. Oturuşunda, gülüşünde, konuşmanda ve yaptıklarında herkese aynı şekilde davran. Böyle yap ki, hiçbir nüfuzlu şahıs senin, taraf tutacağın vehmine kapılmasın ve hiç bir zayıf senin adaletinden ümidini kesmesin. Öfkeli olmaktan, sıkıntı ve ızdırap vermekten, halkı rahatsız etmekten, kızgınlığın olan insanlara değişik davranmaktan sakın.( Kayaoğlu, 1986: 203) Dolayısıyla dinin üzerinde önemle durduğu adalet, bütün insan ilişkilerinde karşılıklı saygı ve sevginin gözetilmesi, kişilerin haklarının gerçekleşmesinin sağlanması esasına dayanır. Böylece devlet yöneticisinin vatandaşa, anne babanın çocuğuna, öğretmenin öğrencisine, eşlerin birbirlerine, bir kimsenin arkadaş ve akrabasına gereken ilgi, sevgi ve saygıyı göstermesine, patronun iş̧̧isine hak ettiği ücreti vermesi adalet olup, bunların yerine getirilmemesi ise zulüm olur. Bu yönleri ile adalet herkesin hakkına ve yeteneğine göre korunması, iyilik ve yardımın buna göre yapılmasıdır. ( Hökelekli, 2013: 76)

Dinin üzerinde hassasiyetle durduğu ve önemsediği adalet değerindeki ilkeler, çalışan kadının hak ettiği ücretin kendisine verilmesi başta olmak üzere iş ortamında ona haksızlık yapmama, aşırıııktan kaçınma, ıımlı davranma gibi ölçülere dikkat edilmesi, ev ortamında da ev işleri ve çocuk bakımında kendisine yardımcı olunma ya da yükünün hafifletilmesi noktasında bir destekte bulunulması gibi bazı uygulamalarla hayata geçirilebilirse çalışan kadının sorunlarının çözümünde fonksiyonel olabilir. Bunun için de gerek örgün, gerekse yaygın din eğitiminde, toplumun her kesiminde adalet değeri üzerinde gerektiği şekilde durulmalı ki; günlük hayatımızda insanlar arasında meydana gelebilecek haksızlık ve zulümlerin önüne geçilebilmeli ve çalışan kadının yaşayabileceği sorunların çözümünde de etkili olabilmelidir. Aynı zamanda adalet değerinin anlamlı bir şekilde anlatılması ve uygulanması toplumda huzur ve uyumun da oluşmasına imkan sağlayabilmelidir.

Sorumluluk değeri de kişiyi değerli kılan ve kurallara uyabilme, çevresine karşı ilgili ve duyarlı olma, sözünde durma, ciddiyet, güven, başkalarının haklarına saygılı olma gibi bazı temel özellikleri barındırır.( Hökelekli, 2013: 58) Bu itibarla sorumluluk "kiş̧inin kendisine ve başkalarına özen ve bakım göstermesini, yükümlülüklerini yerine getirmesini, toplumsal sürece katılmasını, acıları dindirmeye çalışmasını ve daha iyi bir dünya için gayret etmesini ihtiva eden bir erdem" olarak tanımlanabilir. (Hökelekli, 2013: 57) Bütün bu özellikleri nedeniyle Kur'an-ı Kerim'de Allah insanı halife sıfatıyla yeryüzündeki tüm varlıkları yönetme ve onların sorumluluğunu üstlenme (Bakara, 2/30; En'am,6/165; Yunus,10/14) ve adaletli bir düzen oluşturma (Nisa,4/58) görevi ile görevlendirmiştir. ( Hökelekli, 2013: 65) Böylece sorumluluk değeri insanın ve bütün varlıkların haklarına riayet etme- 
yi ve onların haklarını koruma noktasında kişinin görev ve sorumluluğu olduğunu da hatırlatır sorumluluk ve adalet değeri birbiriyle ilişkili ve birbirini tamamlayan bir değer olarak ta karşımıza çıkmaktadır. Bu itibarla çalışan kadının sorunlarının çözümünde hem adaleti sağlamada hem de aile ve iş ortamında kadına karşı sorumlulukların yerine getirilmesinde sorumluluk değeri son derece önem arz etmektedir. Zira sorunların çözümü sorumlulukların yerine getirilmesi ile mümkün olabilecektir. Bu nedenle gerek sorunların oluşumunu ortadan kaldıracak şekilde gerekse var olan sorunların çözümünde sorumluluk duygusu etkili olabilir. Bunun için de çalışan kadının ev- iş ilişkileri açısından eşinin iş ortamındaki konumu ve ilişkileri yönüyle de işveren ya da yönetici ile çalışma ortamındaki diğer bireylerin sorumluluk değerinin anlam ve önemini kavramalarını sağlayacak etkinlikler düzenlenebilir.

Bireyin hayatında en çok gerçekleştirmesi gereken ve ilişkilerini anlamlı sürekli kılacak olan doğruluk, "kişinin inanç niyet ve düşüncelerinde, işlerinde, söz ve davranışlarında, hakikate, adalete gerçeğe uygunluktur". ( Hökelekli, 2013: 164) Doğruluk söz ve davranışlar arasında bir tutarlığın olmasıdır. Kişinin söz ve ifadelerinde gerçeği söylemesi söz konusudur. Gerçekleri gizlemek ya da saptırmak doğrulukla çelişen bir durumdur. Bu nedenle doğruluk gönülden, içten gelerek, samimi bir şekilde hakkı verilerek yapılan eylemlerdir. Gösteriş, kendini önemsetmek ya da sadece kendini düşünerek davranmak doğruluğa aykırı durumlardır.( Hökelekli, 2013: 164) Doğruluk ilkesi içerisinde davranılmazsa insan ilişkileri sorunlu hale gelir. Birbirine güven kaybolur, içi ve dışı farklı olur, ne yapacağı belli olmaz ve bir belirsizlik oluşur. İnsanları aldatan, sözünde durmayan, çelişkili davranan bir görünüm sergilenir. Bütün bu durumlar bireyin sosyal hayatında ciddi sorunlar oluşturur. Çalışan kadın iş ortamında doğruluk ilkesi ile hareket edilmediğinde kendini güvende hissedemeyebilir, her an neyle karşılaşacağını bilemez ve samimi bir ortam oluşamayacağından verimli bir üretimde bulunamayabilir. Bu durumlar çalışan kadının en çok etkilenebileceği sorunlar arasında yer alır. Bu itibarla çalışan kadının veriminin artması, güven ortamında işini yürütebilmesi, sağlıkı ilişkilerin yer aldığı huzurlu bir iş ortamının oluşması elbetteki doğru dürüst davranmakla mümkün olabilecektir. Doğruluk ilkesi bu noktada dikkate alınması gereken ve çalışan kadının sorunlarının çözümünde yararlanılması gereken önemli bir değer olarak karşımıza çıkmaktadır.

Sorumluluklarını hakkıyla yerine getiren, adil davranan ve doğruluk ilkesini gözeten kişi güvenilir kimse olacaktır. Bunların sonucunda ortaya çıkan güven değeri insanın hayatında düzenleyici, kalıcı, devamlı, tutarlı bir yaşamın oluşmasında da etkili olur. Bu nedenle güven, özünde bir kişinin karşısındakinin adil, ahlaki kurallara uygun ve öngörülebilir biçimde davranacağına ilişkin inancını ihtiva eder. Karşısındakine itimadı yansıtır.(Hökelekli, 2013: 210) Dolayısıyla güven değeri güvenilen ve güvenen olma hali itibarıyla sosyal ilişkileri düzenleyen ve sürekliliğini sağlayan bir değer olarak karşımıza çıkar. Güven değerinin bu özellikleri çalışan kadının sorunlarının çözümünde önemli bir rolü bulunabilir. Çünkü çalışma ortamında işveren ya da yönetici çalışan kadına doğru dürüst davranarak, haklarını riayet ederek, adaletli davranarak güven ortamı oluşturacağı için çalışan kadının karşılaşacağı sorunları aşmada bu durum etkili olabilecektir. Güven, insani ilişkilerin ve elde edilen imkanların devamlıı̆̆ı noktasında vazgeçilmez bir değerdir. Güvenin olmadığı bir ortamda insan ne kadar çok imkanı olursa olsun, iyi bir işi ve yaşam koşullarına sahip olsa da bunların değeri olama- 
yacaktır. Zira güvenin olmadığı bir ortam zarar görme ve tehlike içinde olma, korku, endişe ümitsizlik vb. durumu ortaya çıkaracağından sahip olunan imkanlar anlamını yitirebilecektir. Bu nedenle güven duygusunun insan hayatında taşıdığı önem sebebiyledir ki iman da "emn" kökünden güven anlamına sahiptir. (Okuyan, 2013: 98) İman Allah'a güvenmek, ondan zarar ve tehlike gelmeyeceğini bilmektir. Bu sebeple Allah kendini zulüm yapmayan olarak tanıtır. (Örnek ayetler; Al-i İmran, 3/117; Enfal, 8/51; Yunus,10/44; Hud,11/101; Nahl,16/33)

Güven duygusu aynı zamanda samimiyeti, dostluğu karşısındakini anlamayı sağlar ve sadakati, vefayı, adaleti saygı ve sevgi gibi değerlerle de doğrudan ilişkilidir. ( Hökelekli, 2013: 210) Bu açıdan insani ilişkileri sürdürebilir kılmada ve sorunların çözümünde insanları olduğu gibi kabullenmede onlarla ilgilenme, onlara sevecen, sempatik davranmada etkili olan şefkat değerinin de varlığı ortaya çıkar. Şefkat değeri, insanların iyi özelliklere sahip olmalarını arzu etmeye, onları zarara sevkedecek yanlış ve kötü şeylerden korumaya yönelik davranmayı sağlar. ( Hökelekli, 2013: 199) Şefkat, başkalarını anlamayla yakından ilgili olduğundan , onların ne düşündüğü değil ne hissettiğini anlamak önemlidir. Bu nedenle çalışan kadının yaşadıklarını anlamak, hissettiği şeylerin anlaşıldığını fark ettirmek, onun iş ortamında ya da ev iş ilişkisi içerisinde yaşadığı sorunların çözümünde de etkili olabilir.

Çalışan kadınların sorunlarının çözümünde bütün değerlerin temelini oluşturan sevginin çok önemli bir yeri bulunmaktadır. Çünkü sevgi, kişinin bütünlüğünü sağlar ve bireyselliğini gerçekleştirir aynı zamanda diğer insan ve varlıklarla da birleştirir. ( Hökelekli, 2013: 15) Sevgide iki kişiyi birbirine yaklaştırma ve bütünleştirme gücü vardır. İnsanlar arasında barış, uzlaşma, hoşgörü, yardımseverlik, fedakârlık gibi olumlu değer ve davranışların gelişmesine kaynak oluşturur. Güven, dostluk, bağlanma, sempati, şefkat gibi duygu ve eğilimlerin temelinde de sevginin büyük katkısı vardır.

İnsan hayatında son derece anlam ve önemi olan sevgi, kaynağını dinden alarak ve varlıklar arasındaki ilişkinin temel dinamiklerinden biri olarak, "Yaratandan ötürü yaratılanın sevilmesi" değerini insana kazandırırken, çalışan kadının sorunlarının çözümünde de önem arz etmektedir. Zira çalışan kadın da başta çalışma hakkı olmak üzere bazı temel haklara sahiptir. Bu nedenle çalışan kadın ailesi ve birlikte çalıştığı arkadaşlarının ilgisine, desteğine, dinlenme, kendine zaman ayırma, arkadaşları ile birlikte zaman geçirme vb ihtiyaçları olan bu özellikleri ile diğerlerinin yaşadıklarını, hissettiklerini, aynı şekilde yaşayan ve hisseden kişidir. Bir başka ifadeyle, çalışan kadın, temelde aynı psikolojik, fizyolojik, sosyal ve duygusal özelliklere sahiptirler. Dolayısıyla yaratandan ötürü yaratılanı sevme değeri çerçevesinde çalışan kadının da, çalışmasının getirdiği yoğunluğa rağmen, bir insan olarak herkes gibi bazı temel ihtiyaçlarının olduğu düşünülerek, onu anlama ve tanıma konusunda gayret edilirse, çalışan kadın da çalışma ortamından kaynaklanan yaşayabileceği sıkıntı ve zorlukları daha kolay aşabilir ve yaptığı işi de severek yapabilir. 


\section{7. Öneriler}

Çalışan kadının karşılaştığı sorunların çözümünde önemli rolü olabilecek davranış biçimlerinden biri olarak ele aldığımı dini inanç ve değerler eğitimine önem verilmeli. Bu konuda kurum içi seminer vb etkinlikler ile çalışanlara katkı sağlanabilir. Ayrıca bu konu bilimsel açıdan çalışma hayatındaki alanları da dikkate alarak araştırma konusu yapılabilir. Konu erkeklerle de ilişkili olarak ele alınabilir. Medya aracılığı ile de çalışan kadının sorunlarının çözümünde değerler konusu üzerinde durulabilir.

\section{Sonuç}

Çalışan kadının gerek aile ekonomisine katkı amacıyla gerekse kendi hayatını sürdürebilmek için çalışma hayatında yer alması, onun önemli bir özelliği olmakla birlikte çalışma hayatından kaynaklanan ya da aile ortamı ve sosyal yaşamı ile iş arasındaki bazı sıkıntıların sonucu birtakım sorunlarla karşılaşması da çalışan kadının hayatını etkilemektedir. Çalışan kadının karşılaştı̆̆ı sorun ve sıkıntıların çözümü çalışma hayatındaki verimini arttırtacağı gibi işve aile hayatı arasında olabilecek zorlukları da aşmasına katkı sağlayabilecektir. Çözüm noktasında hukuki düzenlemeler yanında psiko-sosyal destek yapılabilecekler arasında zikredilebilecek hususlar olmakla birlikte insan hayatında sahip olduğu özellikler nedeniyle dini inanç ve değerler de önemli bir yer tutar. Dini inanç, insanın aşkın bir varlığa inanması ile birlikte karşılaştığı zorluk ve sıkıntıları aşmada başvurduğu önemli etkinlik olma özelliğine sahiptir. Zira Allah’a iman bireyin kendisine yakın olan ve her an yardımını hissedeceği güçlü bir varlığı hissetmesi ve bu sayede zorlukları aşacağı inancını taşıyarak mücadele etme gücünü ona kazandıran inançtır. Aynı şekilde dini inançtan beslenen dini değerler de kişinin hayatına anlam katma ve zorluklar karşısında çözüm oluşturma özelliği ile ayrı bir öneme sahiptir. Çalışan kadın dini inancı sebebiyle tutarlı davranma becerisi ve sorumluluk bilinci ile davranmaya özen göstererek karşılaştığı sorunları aşmaya çalışır. Ayrıca Allah'a iman ile O'nun kendisine yardımcı olacağı inancı çalışan kadının sorunları aşma gücünü oluşturur. Allah'a imanın yanında ahrete iman da bireyin öldükten sonra yaptıklarının karşılığını alacağı düşüncesi çerçevesinde dikkatli ve sorumluluk bilinci ile davranmasına katkı sağlar. Aynı zamanda sorunlar karşısında pes etmeden çözüm üreterek olumlu karşılığı olacağı inancıyla da kendini güçlü ve mücadele edebilecek şekilde iyi hisseder. Dini değerler açısından da çalışan kadın hak edenin hakkını verme ve alma esasına dayanan adalet,işini severek yapmayı sağlayan sevgi, insanlara katkı sağlamanın ve onlara iyi davranmanın önemini anlatan şefkat ve üzerine düşen işi en iyi şekilde yapma duygusunu öne çıkartan sorumluluk, güvenilir olmanın iş hayatında başarıyı sağlayan sorunlar karşısında çözümü oluşturacak kişilik özelliğini yansıtan yönüyle güven değeri ile birlikte doğru dürüst olma değeri de güven değerini oluşturmadaki etkisi yanında sorunları aşacak manevi gücü hissetmesine vesile olabilecek dini değerlerdendir. Bu değerler çalışan kadının hayatına anlam katma ve sorunları çözme becerisi ile birlikte manevi destek olarak önem kazanmaktadır. 
M.Naci KULA

\section{Kaynaklar}

Acar, M. (2012). Allah’a İmanın Ahlaki Boyutu, (Yayınlanmamış Doktora Tezi)

Akdemir, B\&Duman,M. ( 2016). “Duygusal Bağılıık İ̧̧ Gören Performansı Arasındaki illişkiye Yönelik Bir Araştırma," The Journal of Academic Social Science Studies, Number: 46 , p. 343-357, Spring IV 2016

Cevher, E.\& Öztürk, U.” İ̧̧ Yaşamında Kadınların Kadınlara Yaptığı Mobbing Üzerine Bir Araştırma” Insan ve Toplum Bilimleri Araştırmaları Dergisi Cilt: 4, Sayı: 4, 2015. s.861-876

Çullu, S. ( 2009). Türkiye'de Çalışan Kadınların İşgücü Piyasasındaki Konumları ve Karşılaştıkları Sorunlar, ( Yayınlanmamış Yüksek Lisans Tezi) Eskişehir Osmangazi Üniversitesi Sosyal Bilimler Enstitüsü

Erkek, S.\&Karagöz, H. (2009). Kadının Iş Hayatındaki Yeri ve Karşılaştığı Sorunlar, Konya Ticaret Odası

Elmalı, A.(1997). Kur'an-ı Kerimde Adalet (Adl) Kavramı, Harran Üniversitesi Ilahiyat Fakültesi Dergisi, III, 1997.s. 283-328

Gözütok, Ş. ( 2016). Resulullah Döneminde Kadın ve Kadın Eğitimi, Dini Araştırmalar, Kadın Özel Sayısı, C.19, Sayı 49 2016. S. 175-196.

Gül, H; Yalçınoğlu, N; Atlı, C. Z. ( 2014). Türkiye'de Çalışma Yaşamında Kadının Konumu ve Sorunları, TAF Prev Med Bull 2014:13(2) s. 169-176

Hökelekli, H.( 2007). Dini hayatın Bütünlüğü Açısından Ahirete İnancının Psikolojik Temelleri, 2930 Haziran 2007 Kelam Anabilim Dalı Koordinasyon Toplantısı içinde İslam'da Ahiret İnancı Sempozyum Bildirisi, http://www.kelam.org/web/conferences/38 Erişim tarihi 09.10.2017

Hökelekli, H. (2009). Din Psikolojisi, Ankara:TDV Yayınları

Hökelekli, H.(2013). Insani Değerler, İstanbul: DEM Yayınları

Karaali, R. (2016). Kadınların Çalışması, Çorum'da Imalat Sektöründe Çalışan Kadınların Çalışma hayatında Yaşadıkları Sorunların Verimliliğe Etkisi, (Yayınlanmamış Yüksek Lisans Tezi) Hitit Üniversitesi Sosyal Bilimler Enstitüsü

Karaca, F. ( 2015). Din Psikolojisi, Trabzon : Eser Ofset Matbacllık

Koray, M. (1999). Calısma Yasamında Kadın Gercekleri , İzmir: Basisen Yayını

Köse, A.\& Ayten, A. ( 2012). Din Psikolojisi, İstanbul: Timaş yayınları 
Kula, N.(2012). Bakıma Muhtaç Kişilere Yönelik Sosyal Hizmetler ve Dini Değerler, Altaş, N. \&Köylü,M.(Edt) Dini Danışmanlık ve Din Hizmetleri, (s.188-202) Ankara: Gündüz Eğitim ve Yayıncılık

Küçük, M.(2015). Çalışma Hayatında Kadınlar ve Karşılaştıkları Sorunlar: Bir İşverene Bağlı olarak Çalışan Emekçi Kadınlara iliş̧in Bir Araştırma, Ekonomi Bilimleri Dergisi, Cilt 7, No 1, 2015 s.117

Mehmedoğlu, U.(2006). Küreselleşme Ahlak ve Değerler, Y. ve A. Mehmedoğlu (Edt). Gençlik Değerler ve Din (s. 258-265), İstanbul: Litera Yay

Mengüşoglu, T. ( 1988). Insan Felsefesi. İstanbul: Remzi Kitabevi.

Mercanlıoğlu, Ç. (2009). Cinsiyete Dayalı Eşitsizlik; Kadın Yöneticilerin ĠG̣ Ve Özel Hayatlarını Dengeleme Zorlukları Ve Bedelleri, Disiplinlerarası Kadın Çalışmaları Kongresi Kongre Bilgileri, C.1, Sakarya: Sakarya Üniversitesi Basımevi

Okuyan, M. (2013). Kuran'ı Kerim'de çok anlamlılık, İstanbul: Düşün Yayıncılık

Şahin, M.(2005). Çalışan Kadınların İşyerindeki Sorunları : Erzurum Alışveriş Merkezleri Örneği, (Yayınlanmamış Yüksek Lisans Tezi) İnönü Üniversitesi Sosyal Bilimler Enstitüsü

Şekerci, O. (2001). İnanç ve İs, İstanbul: Rağbet Yayınları.

Tekdemir, B.(2015). "Doğruluk" A.A. ve Ü.Akın (Edt) Psikolojide Güncel Kavramlar-VI-Değeler, (s.171-184) Ankara, Nobel Yay.

Uyanık, N. (2010). Kur’an Bağlamında Ahirete İmanın İnsan Eğitimindeki Rolü, ( Yayınlanmamış Yüksek Lisans Tezi) Ankara Üniversitesi Sosyal Bilimler Enstitüsü

Uysal, E. (2003). Değerler Üzerine Bazı Düşünceler ve Bir Erdem Tasnifi Denemesi: İnsani Erdemlerİslami Erdemler", Uludağ Üniversitesi Illahiyat Fakültesi Dergisi, 12 (1), 2003, s. 51-69.

Yaşar, O. (2014). Çalışan Kadınlarda Örgütsel Stres ve Başa Çıkma Yolları, (Bir Kamu Örneği), (Yayınlanmamış Yüksek Lisans Tezi), Bilecik Şeyh Edebali Üniversitesi sosyal Bilimler Enstitüsü

Yıldız, B.(2015) "Sorumluluk", A.A. ve Ü.Akın (Edt) Psikolojide Güncel Kavramlar-VI-Değerler, (s.160-171) Ankara, Nobel Yay.

Internet siteleri

http://gazetemanifesto.com/2017/03/08/kadin-emegi-raporu) Erişim Tarihi:09.10.2017

www.tuik.gov.tr/PreHaberBultenleri.do?=21573 Erişim Tarihi:09.10.2017

https://www.dunya.com/gundem/kayit-disi-calisma-kadinlarda-yuzde-47-erkeklerde-yuzde-28-

haberi-290666 Erişim Tarihi:09.10.2017 